\title{
ЕВОЛЮЦІЯ КОНЦЕПЦІЇ ВІДПОВІДАЛЬНОСТІ АВІАПЕРЕВІЗНИКА: НАЦІОНАЛЬНИЙ ТА МІЖНАРОДНИЙ АСПЕКТИ
}

\begin{abstract}
Анотація. Розвиток авіації безпосередньо пов'язаний з розвитком науково-технічного прогресу та рухається тими ж темпами. При цьому відбуваеться постійне збільшення кількості повітряних транспортних засобів і їх вдосконалення в напрямку збільшення обсягів перевезень і посилення безпеки повітряних перевезень. Обумовлено це необхідністю задоволення зростаючих вимог в перевезеннях пасажирів і вантажів, які здійснюються за внутрішніми і міжнародними маршрутами. В міру розширення міжнародної комунікації, розвитку економічних, в тому числі торговельних і промислових відносин між державами, ростуть і обсяги перевезень, і в майбутньому зазначена тенденція зростання буде зберігатися. В поданій статті розглядаеться поняття авіаційної події та аналізуються правові наслідки неналежного виконання умов договору повітряного перевезення через призму національного та міжнародного повітряного права. Аналізуються питання щодо комплексного застосування норм Варшавської конвенщії 1929 року та норм Монреальської Конвенції 1999 року під час розгляду спорів між пасажиром та авіаперевізником за договором повітряного перевезення при здійснення авіаперевізником міжнародних та внутрішніх рейсів.
\end{abstract}

Ключові слова: відповідальність перевізника, міжнародні повітряні перевезення, Варшавська конвенція 1929 р., Монреальська конвенція 1999 р., Цивільний кодекс України.

Koptenko Anna, Panfilova Yulia Kyiv International University

\section{EVOLUTION OF THE CONCEPT OF AIR CARRIER LIABILITY: NATIONAL AND INTERNATIONAL ASPECTS}

Summary. The development of aviation is directly related to the development of scientific and technological progress and is moving at the same pace. At the same time, there is a constant increase in the number of air vehicles and their improvement in the direction of increasing the volume of traffic and strengthening the safety of air traffic. This is due to the need to meet the growing demands in the transportation of passengers and goods, which are carried out on domestic and international routes. With the expansion of international communication, the development of economic, including trade and industrial relations between the states, the volume of traffic is growing, and in the future this growth trend will continue. This article considers the concept of an aviation event and analyzes the legal consequences of improper compliance with the terms of the contract of carriage through the prism of national and international air law. The issues of complex application of the norms of the Warsaw Convention of 1929 and the norms of the Montreal Convention of 1999 in the consideration of disputes between a passenger and an air carrier under an air transportation contract in the implementation of international and domestic flights by the air carrier are analyzed. The advantage of this document was the unification of the rules of international air transportation, the need for which was caused by the complexity and inconsistency of various legal sources governing liability under the contract of carriage, which often caused difficulties in correctly determining the legal regime of liability for breach of contractual obligations. Causing harm to the lives or health of passengers. It is noted that the improved international document, namely the Montreal Convention, has a fundamentally different legal regime for international air transportation, which increases the guarantees of airline passengers and the quality of services provided. It is substantiated that both conventions define important rules of international air transportation concerning the conclusion of a contract of carriage, some of its conditions and, most importantly, the carrier's liability for damage to life and health of passengers, luggage, cargo and delays in its delivery. The main subject of regulation.

Keywords: carrier's liability, international air transportation, Warsaw Convention of 1929, Montreal Convention of 1999, Civil Code of Ukraine.

$\Pi$ остановка проблеми. Розвиток авіації безпосередньо пов'язаний 3 розвитком науково-технічного прогресу і рухається тими ж темпами. При цьому відбувається постійне збільшення кількості повітряних транспортних засобів і їх вдосконалення в напрямку збільшення обсягів перевезень і посилення безпеки повітряних перевезень. Обумовлено це необхідністю задоволення зростаючих вимог в перевезеннях пасажирів і вантажів, які здійснюються за внутрішніми і міжнародними маршрутами. В міру розширення міжнародної комунікації, розвитку економічних, в тому числі торговельних і промислових відносин між державами, ростуть і обсяги перевезень, і в майбутньому зазначена тенденщія зростання буде зберігатися.
Однак, не дивлячись на те, що повітряний транспорт справедливо вважають найбезпечнішим і найшвидшим транспортом, збільшення обсягів повітряних перевезень неминуче тягне пропорційне збільшення випадків заподіяння шкоди життю і здоров'ю осіб, пошкодження або втрати багажу, що перевозиться та вантажу.

Правове регулювання відносин, пов'язаних з повітряним перевезенням пасажирів і багажу, значною мірою відрізняеться від регламентації інших видів договірних зобов'язань. Досить сказати, що договір перевезення мае абстрактний характер і виявляє себе у колі транспортних договорів, визначених врегульовувати певні правовідносини. 
Співробітництво держав у галузі повітряних перевезень проявилось у прийнятті ряду міжнародних договорів, які одержали назву «Варшавська система». Варшавська Конвенція 1929 р., яка була ратифікована Україною 14.08.1959 р., $є$ однією із основних міжнародних угод про умови повітряних перевезень пасажирів і багажу між державами. Приєднання України до Варшавської Конвенції 1929 р. та ряду інших визначило новий етап для розвитку відносин в галузі міжнародних повітряних перевезень.

Актуальності дослідження питань відповідальності перевізників при здійсненні повітряного перевезення додало прийняття Конвенції для уніфікації деяких правил міжнародних повітряних перевезень. Зазначений документ було прийнято 28 травня 1999 року на Міжнародній конфреренції з повітряного права, що проходила під егідою Міжнародної організації цивільної авіації (IКАО) у Монреалі і набрала чинності 4 листопада 2003 року. Перевагою даного документу стала уніфікація правил міжнародних повітряних перевезень, необхідність якої була викликана складністю і суперечливістю положень різних правових джерел, що регламентують відповідальність за договором повітряного перевезення, що часто викликала труднощі в правильному визначенні правового режиму відповідальності за порушення перевізниками своїх договірних зобов'язань і за заподіяння ними шкоди життю або здоров'ю пасажирів.

Таким чином, укладання договору повітряного перевезення та належне виконання сторонами істотних умов договору - одна із основних і сучасних проблем національного та міжнародного повітряного права.

Аналіз досліджень та публікацій. ПідIрунтям для дослідження проблем міжнародно-правової відповідальності авіаперевізника слугують праці українських, російських та іноземних вчених-правників: Баймуратов М. О. [1], Бойко М. О. [2], Бордунов В. Д. [3], Короткий Т. Р. [7], Маловацький О. В. [8], Остроумов Н. Н. [10], Сігал К. О. [13], Смислова Н. Н. [14], Столяровський О. В. [15], Авраам Х. [18], Гулдіманн В. [19], Марк Макдоналд [20], Рільзе О. [21].

Мета статті полягає в тому, щоб, спираючись на чинне законодавство, міжнародні договори, погляди вчених дослідити особливості відповідальності авіаперевізника за порушення договору авіаперевезення.

Виклад основного матеріалу. Авіаційний транспорт справедливо займає особливе місце в світовій транспортній системі. Переваги повітряного транспорту в першу чергу пов'язані 3 високою швидкістю перевезення пасажирів і вантажів. Крім џьог, повітряний транспорт в силу своєї специфіки може забезпечувати регулярність перевезень, не пов'язаних 3 сезонними коливаннями, так як це відбувається при морському перевезенні або перевезенні внутрішніми водними шляхами, які можуть здійснюватися тільки в період літньої навігації. Перевагою авіаперевезень є великий вибір маршрутів, незалежно від наземної інфраструктури. Серед пасажирських перевезень повітряний транспорт надає високий рівень сервісу, що в поєднанні 3 високою швидкістю перевезень, робить пові- тряний транспорт привабливим для пасажирів та відправників вантажу.

Попри вищезгадані переваги, цей вид транспорту також несе в собі ризики аварій, нещасних випадків - авіаційних подій. Найстрашніша авіакатастрофра за участю двох літаків сталася в 1977 рощі на Канарських Островах, при спробі зльоту в аеропорту Тенеріфре (Іспанія) Boeing-747 голландської авіакомпанії KLM в тумані врізався в Boeing-747 авіакомпанії PanAm. У результаті зіткнення загинуло 578 осіб. Зіткнення авіалайнерів відбулося через мовний бар'єр: голландські пілоти погано розуміли команди диспетчера, який говорив англійською з іспанським акцентом. У 1985 році сталася авіакатастрофра, яка вважається рекордом за кількістю пасажирів, які загинули під час падіння одного літака протягом останніх 40 років. На борту японського Boeing-747 знаходилися 524 людини, 3 яких врятувалося тільки четверо. Причиною аварії виявився неякісний ремонт повітряного судна. Як бачимо, до авіаційної події може призвести, як несправність повітряного судна, так і людський фрактор. Згідно з даними ІКАО, протягом багатьох років розвитку авіації кожні три з чотирьох авіаційних подій траплялися в результаті неуважності чи поганій працездатності людини [11].

Поняття авіаційної події $е$ узагальнюючим терміном та основне його тлумачення в міжнародному праві закріплене в Додатку 13 Конвенції про міжнародну цивільну авіацію [6].

Воно включає в собі три важливі визначення:

- «авіаційна пригода» (accident);

- «інцидент» (incident);

- «серйозний інцидент» (serious incident).

Авіаційна пригода - це подія, пов'язана 3 використанням повітряного судна, при якій особа, що перебуває на борту зазнає фрізичних тяжких тілесних ушкоджень, ушкоджень із смертельними наслідками (виняток становлять ушкодження завдані собі самому та ті, які настали внаслідок природніх причин), i/або коли повітряне судно одержуе пошкодження та відбувається його руйнування, або зникає безвісті в невідомому напрямку, не подаючи ніяких розпізнавальних сигналів, або перебуває в місці з обмеженим доступом. При класифрікації авіаційних пригод (далі - АП), їх необхідно розподіляти на АП 3 людськими жертвами і АП без людських втрат у відповідності з вимогами IКАО.

Інцидент - це будь-яка інша подія, окрім авіаційної пригоди, що пов'язана 3 використанням повітряного судна, яка впливає або могла вплинути на безпеку польоту.

Серйозний інцидент - це авіаційна подія 3 більш серйозними наслідками ніж інцидент та меншими ніж авіаційна пригода. Його обставини вказують на те, що була велика ймовірність трапитись авіащійній пригоді. Прикладом серйозного інциденту є авіаційна подія, яка трапилась у львівському аеропорті: «12.10.2020 о 12:18 UTC при виконанні приватного польоту за маршрутом Цунів-Львів на літаку РА-30 N-918Y (США), під час післяпосадкового пробігу з курсом $180^{\circ}$ сталося складання усіх трьох опор шасі, що в подальшому призвело до руйнування гвинтів обох двигунів та зупинки літака на ЗПС. Пожежі не було. Екіпаж та пасажир не постраждали. 
Розслідування серйозного інциденту проводить НБРЦА» [12].

Враховуючі зазначене питання правової регламентації відповідальності авіаперевізника постає досить гостро.

Юридична відповідальність як одна із форм соціальної відповідальності, згідно 3 фрундаментальними положеннями національного права, полягає в передбаченому законом застосуванні до правопорушника 3 боку держави деяких санкцій за скоєне ним правопорушення. Оскільки правовідносини 3 приводу перевезення виникають на основі договору, до сторін договору застосовуеться договірна відповідальність. Вона настае для сторони договору 3 моменту невиконання нею своїх обов'язків, тобто порушення умов договору та настання для порушника негативних наслідків. Це положення стосується всіх суб'єктів правовідносин (як фізичних, так і юридичних осіб). Поняття юридичної відповідальності в міжнародному праві визначається терміном liability, який означає юридичну відповідальність (legal responsibility) за дії (acts) або бездіяльність (omissions) [17].

Як зазначає, Смислова Н. Н., регламентація відповідальності авіаперевізників повинна забезпечити вирішення двох головних завдань:

- надавати достатній захист організаціям i особам, які користуються послугами повітряного транспорту,

- стимулювати до належної організації транспортного процесу і не породжувати для них надмірних фрінансових труднощів, які можуть бути дуже значними щодо нормальної діяльності авіакомпаній малих та особливо розвинутих країн [14, с. 177].

У національному законодавстві існуе низка норм, які регулюють правовідносини у сфері здійснення перевезень, і також норми, які передбачають відповідальність перевізника при здійсненні таких перевезень. Керуючись нормами вітчизняного законодавства та розглядаючи практику здійснення повітряних перевезень пасажирів та багажу, можна виокремити такі види відповідальності перевізника: ЦК України [16] передбачає, що за договором перевезення перевізник зобов'язується доставити пасажира чи багаж до пункту призначення за встановлену плату.

Відповідальність за прострочення у доставиі (ст. 919 ЦК України [16]) передбачає зобов'язання перевізника доставити вантаж, пасажира, багаж, пошту до пункту призначення у строк, встановлений договором, якщо інший строк не встановлений транспортними кодексами (статутами), іншими нормативно-правовими актами та правилами, що видаються відповідно до них, а в разі відсутності таких строків - у розумний строк.

За загальним правилом визначеним ЦК України, відповідальність за зобов'язанняли, шо випливають із договору перевезення (ст. 920 ЦК України [16]) встановлюеться сторонами за домовленістю, якщо інше не встановлено ЦК України, іншими законами або транспортними кодексами (статутами).

Відповідальність перевізника за затрилку відправлення пасажира та порушення строку доставлення пасажира до пункту призначення (ст. 922 ЦК України [16]) передбачена:

- за затримку у відправленні транспортного засобу, що перевозить пасажира, або запізнення у прибутті такого транспортного засобу до пункту призначення перевізник сплачуе пасажирові штраф у розмірі, встановленому за домовленістю сторін, транспортними кодексами (статутами), якщо перевізник не доведе, що ці порушення сталися внаслідок непереборної сили, усунення несправності транспортного засобу, яка загрожувала життю або здоров'ю пасажирів, або інших обставин, що не залежали від перевізника;

- у разі відмови пасажира від перевезення 3 причини затримки відправлення транспортного засобу перевізник зобов'язаний повернути пасажиру провізну плату;

- якщо поїздка пасажира з пункту пересадки не відбулася внаслідок запізнення транспортного засобу, який доставив його у цей пункт, перевізник зобов'язаний відшкодувати пасажирові завдані збитки.

Відповідальність перевізника за втрату, нестачу, псування або пошкодження вантажу, багажу, пошти (ст. 924 ЦК України [16]) передбачає, що перевізник відповідає за збереження вантажу, багажу, пошти 3 моменту прийняття їх до перевезення та до видачі одержувачеві, якщо не доведе, що втрата, нестача, псування або пошкодження вантажу, багажу, пошти сталися внаслідок обставин, яким перевізник не міг запобігти й усунення яких від нього не залежало. Перевізник відповідає за втрату, нестачу, псування або пошкодження прийнятих до перевезення вантажу, багажу, пошти в розмірі фрактичної шкоди, якщо не доведе, що це сталося не з його вини. Підтвердженням укладення договору повітряного перевезення пасажира $є$ пасажирський квиток та багажна квитанція.

Разом 3 цим, передбачена відповідальність перевізника за шкоду, завдану каліцтвом, іншил ушкодженнял здоров'я або слертю пасажира (ст. 928 ЦК України [16]), яка визначається відповідно до глави 82 ЦК України [16], якщо договором або законом не встановлена відповідальність перевізника без вини.

Що стосуеться конвенційних стандартів відповідальності повітряного перевізника та практика їх застосування, слід зазначити, що Остроумов М. М. вважає, що Варшавська і Монреальська Конвенції [4; 6] виходять 3 правової концепщії відповідальності авіакомпаній в рамках договору повітряного перевезення. Хоча жодна 3 Конвенщій не містить визначення договору повітряного перевезення, з істоти їх загальних положень випливає, що у центрі взаємовідносин перевізника та його клієнтів е договір (угода), що відповідальність перевізника настае у разі невиконання або неналежного виконання ним своїх обов'язків за договором перевезення, головною 3 яких є своєчасна і безпечна доставка пасажирів, багажу і вантажів у пункт призначення [10, с. 52].

Що ж нами це підтримуеться, оскільки загальні положення Варшавської Конвенції [4] та Монреальської Конвенції [6] відображають в ній правову концепцію відповідальності авіаперевізника за договором повітряного перевезення у наступних положеннях:

1. Перевізник несе відповідальність за шкоду, заподіяну пасажиру та багажу в період виконання повітряного перевезення (ст 17, 18 Варшавської Конвенції [4] та Монреальської Конвенції [6]). 
2. Відповідальність перевізника наступає при наявності його вини, яка може передбачатись (ст. 20 Варшавської Конвенції [4] та Монреальської Конвенції [6]).

3. Встановлена максимальна межа відповідальності перевізника, яка диференційована стосовно до окремих випадків відповідальності (ст. 22 Варшавської і Монреальської Конвенцій $[4 ; 6])$.

4. При наявності грубої вини перевізника він відповідає за заподіяну шкоду в повному розмірі (ст. 25 Варшавської Конвенції [4] та ч. 5 ст. 22 Монреальської Конвенції [6]).

Розглянемо ці положення більш детальніше, оскільки вони відображають у повній мірі принципи відповідальності авіаперевізника за договором повітряного перевезення.

Перевізник несе відповідальність в період повітряного перевезення, яке охоплює період часу, на протязі якого багаж знаходився під охороною перевізника, незалежно від того, сталося це в аеропорту, чи на борту повітряного судна, або в якому іншому місці у випадках посадки літака за межами аеропорту (ст. 18 Варшавської та Монреальської Конвенції [4; 6]). Відповідальність за шкоду здоров'ю пасажира наступає, якщо нещасний випадок стався на борту повітряного судна, або під час різних операщій при посадщі та висадщі (ст. 17 Варшавської і Монреальської Конвенцій $[4 ; 6])$.

Слід зазначити, що на практиці пасажирських перевезень дане положення має деякі неясності. Чи повинні авіакомпанії нести відповідальність перед пасажиром під час його перебування у приміщеннях аеропорту та аналогічних будовах і у зв'язку з посадкою та висадкою пасажирів.

Це обумовлено тим, що у ст. 17 Варшавської Конвенцї [4] та ч. 1 ст. 17 Монральської Конвенції [6] говориться про різні операції при посадці та висадщі, вважаю, що поняття посадки та висадки повинно трактуватися розширено.

Подібне розширене тлумачення може бути у вигляді, що перевізник відповідає за шкоду, яка виникла внаслідок смерті або ушкодження здоров'я пасажира 3 часу входу пасажира на перон аеропорту для посадки в повітряне судно і до часу, коли пасажир покинув перон під доглядом уповноважених осіб перевізника.

Адже, перевізник не несе відповідальності, якщо смерть або погіршення стану здоров'я пасажира стали результатом виключно особливістю його здоров'я.

Принцип відповідальності перевізника за вину сформульований у Варшавській i Монреальській Конвенщіях [4; 6] достатньо чітко. В силу ст. 20 відповідних Конвенцій перевізник звільняеться від відповідальності, якщо ним буде доказано, що він та його агенти прийняли всі необхідні заходи для того, щоб запобігти заподіянню шкоди, або для них було неможливим прийняти такі заходи.

Ці важливі положення виражені у текстах Варшавської і Монреальської Конвенцій [4; 6] і зрозуміло е загальновизнаними.

Крім того, спеціально обумовлена одна із найбільш типових на практиці ситуацій, які виключають вину перевізника - це наявність вини самого потерпілого. Згідно з ст. 21 Варшавської Конвенщії та ст. 20 Монреальської Конвенції, повітряний перевізник частково або повністю звільняеться від відповідальності, якщо доведе, що шкода була визнана виною самого потерпілого і при розгляді спору суд врахуе можливість застосувати по цьому питанню норму свого внутрішнього права.

Так, суди зарубіжних країн у своїх рішеннях, як правило виходять із того, що перевізнику, щоб доказати свою невинність (тобто не нести відповідальність), недостатньо посилатися на прийняті необхідні заходи загального характеру. Перевізник повинен довести наявність обставин, які стали причиною невиконання умов договору повітряного перевезення і не можуть бути поставлені йому у вину. При неясності причин, які призвели невиконання договору перевезення, авіаперевізник за загальними правилами визнається винним і повинен нести за це відповідальність [22, с.166].

Загальновизнано, що правила Варшавської Конвенції [42] та Монреальської Конвенції [6] про вину як умову відповідальності повітряного перевізника відносяться тільки до перевезень пасажирів та багажу, а не до ручної поклажі (незареєстрованого багажу), котра залишається при пасажирові.

У відношенні до ручної поклажі передбачено лише межу відповідальності перевізника. Тому, умови відповідальності перевізника при незбереженні ручної поклажі повинні визначатися за нормами внутрішнього законодавства, яке можливо підлягає застосуванню до договору міжнародного повітряного перевезення [18, с. 61 ; 19 , с. $106 ; 21$, с. 421$]$.

Такий підсумок не являеться безспірним, так як ст. 20 зазначених Конвенцій має загальну редакцію і не згадуе про пасажирів та багаж. Але він став широко розповсюдженим та до цього можна прийти при систематичному тлумаченні ст. 17, 18, 19, 20 Варшавської і Монреальської Конвенцій $[4 ; 6]$.

Правила перевезень IATA, а слідом за ними i Правила перевезень авіакомпаній виходять з того, що відповідальність авіакомпаній за ручну поклажу пасажира наступає тільки у випадках, коли буде доказана вина перевізника. У цьому розумінні вирішують дане питання і національні «Правила повітряних перевезень та обслуговування пасажирів і багажу» [9], які додатково пояснюють, що сприяння пасажиру працівниками авіакомпанії, або його агентами при перевезенні незареєстрованого багажу розглядаються як добра послуга пасажиру. Перевізник не нестиме відповідальності за пошкодження цього багажу під час надання такої послуги, про що чітко зазначено - за ручну поклажу протягом усього перевезення відповідає пасажир.

Висновки. У сучасному світі, де дуже важливе місце посідають авіаперевезення, вагомим питанням $є$ ïх правове регулювання та уніфрікація для будь якої держави. Міжнародне повітряне право спрямоване на захист юридичних прав пасажирів та законодавчо встановлює межі відповідальності авіаперевізника за заподіяну шкоду згідно 3 договором міжнародного повітряного перевезення.

Поняття авіаційної події визначаеться як подія, пов'язана 3 використанням повітряного судна, яка має місце 3 моменту, коли будь-яка особа піднімаеться на борт з наміром здійснити політ, до моменту, коли всі особи, що перебува- 
ли на борту, покинули повітряне судно, і під час якої будь-яка особа отримуе тілесні ушкодження із смертельним наслідком або серйозні тілесні ушкодження, або повітряне судно одержує пошкодження чи руйнування конструкції.

У статті 910 глави 64 «Перевезення» ЦК України [16] закріплено основоположне визначення договору перевезення. За цим договором - одна сторона (перевізник) зобов'язується перевезти другу сторону (пасажира) до пункту призначення, а в разі здавання багажу - також доставити багаж до пункту призначення та видати його особі, яка має право на одержання багажу, а пасажир зобов'язуеться сплатити встановлену плату за проїзд, а у разі здавання багажу - також за його провезення. Укладення договору перевезення пасажира та багажу підтверджується видачою відповідно квитка та багажної квитанції, форми яких встановлюються відповідно до транспортних кодексів (статутів).

Предметом договору $є$ транспортні послуги 3 повітряних перевезень, тобто послуги 3 переміщення людей (пасажирів) відповідним видом транспорту. Саме за допомогою цього договору забезпечуеться реалізація однієї з основних фрункцій транспорту - задоволення потреб населення в переміщенні.

Досліджуючи Варшавську конвенцію, робимо висновок, що цей нормативно-правовий акт є міжнародною конвенцією, яка регулюе відповідальність при настанні авіаційної події у сфері міжнародних авіаперевезень пасажирів, багажу або вантажу повітряними суднами за винагороду. Це була перша всеохоплююча правова база, що регулює авіацію на міжнародному рівні, відіграючи важливу роль у підтримці розвитку галузі та встановленні набору принципів, більшість 3 яких досі $є$ едрективними та складають основу сучасного авіаційного законодавства. Документи Варшавської системи не варто розглядати як єдиний нормативний акт.

Одні держави беруть участь лише у Варшавській конвенції 1929 р., інші - у Варшавській конвенції, зміненій Гаазьким протоколом 1955 року, треті приєдналися до конвенції, зміненої іншими протоколами. Тому більшість держав, що визнають і застосовують Варшавську систему, беруть участь або у Варшавській конвенщії та Гаазькому протоколі, або у Варшавській конвенції, зміненій Гаазьким протоколом і Гвадалахарською конвенцією 1961 року. Найбільше держав (136) $€$ учасниками Варшавської конвенції, зміненої Гаазьким протоколом 1955 року. Щоправда, 86 з них одночасно приедналися до Монреальської конвенції 1999 року і під час міжнародних перевезень зобов'язані застосовувати положення саме ціеї Конвенції.

Ухвалення Монреальської конвенщії 1999 року $є$ великим кроком вперед щодо гармонізації правової системи, що регулює міжнародні повітряні перевезення, а отже, впорядкованості міжнародного повітряного права, надання йому більшої чіткості та логічності. Очевидною новизною $є$ те, що цей документ тепер, на відміну від Варшавської конвенції, представляе единий правовий механізм, а не набір кількох різних нормативноправових актів за застарілою Варшавською системою.

\section{Список літератури:}

1. Баймуратов М. О. Міжнародне публічне право : підручник. Харків : Одіссей, 2008. 704 с.

2. Бойко М. А. Особенности правового регулирования международных воздушных перевозок. Hayчно-методический электронный журнал “Кониепт». 2013. Т. 3. С. 2386-2390. URL: https://e-koncept.ru/2013/53480.htm. (дата звернення: 08.02.2021).

3. Бордунов В. Д. Международное воздушное право : учебное пособие. Москва : НОУ ВКШ «Авиабизнес»; изд-во «Научная книга», 2007. 464 с.

4. Конвенція для уніфрікації деяких правил, що стосуються міжнародних повітряних перевезень (Варшавська Конвенція), підписана у Варшаві 12.10.1929. Ратифікована Україною 14.08.1959 р. Українська РСР у міжнародно-договірних відносинах. Збірник норлативних докулентів 1976-1985 pp. Київ : Політвидав України, 1986. $358 \mathrm{c}$

5. Конвенція про міжнародну цивільну авіацію (Чиказька Конвенція), підписана в Чикаго 07.12.1944. Ратифікована Україною 10.08.1992р. Міжнародне право в докулентах. Москва : Вид. Юрліт, 1982. 602 с.

6. Конвенція про уніфікацію деяких правил міжнародних повітряних перевезень (Монреальська конвенція) від 28.05.1999 р. / Закон України «Про приеднання України до Конвенції про уніфікацію деяких правил міжнародних повітряних перевезень». Ратифікована Україною 17.12.2008 р. Чинна з 06.05.2009 р. Oøбiuiŭний вісник України. 2009. № 33.

7. Короткий Т. Р. Збиття авіалайнера МАУ в Ірані: міжнародні стандарти розслідування авіаційних подій та інцидентів. Електронний журнал "Украӥнське право». Серія: Міжнародне публічне право. URL:https://ukrainepravo.com/international_law/public_international_law/zbyttya-avialaynera-mau-v-irani-mauv-irani-mizhnarodni-standarty-rozsliduvannya-aviatsiynykh-podiy-/ (дата звернення: 05.02.2021).

8. Маловацький О. В. Міжнародно-правове співробітництво держав щодо удосконалення Варшавської системи відповідальності авіаперевізника. Науковий вісник Диплолатичної акаделії Украӥни. 2007. Вип. 13. C. $165-171$.

9. Наказ Державної авіаційної служби України від 26.11.2018 № 1239 «Про затвердження Авіаційних правил України «Правила повітряних перевезень та обслуговування пасажирів і багажу». URL: https://zakon.rada.gov.ua/ laws/show/z0141-19\#Text (дата звернення: 15.02.2021).

10. Остроумов Н. Н. Договор перевозки в международном воздушном сообщении : монография. Москва : Статут, 2009. 268 c.

11. Руководство по обучению в области человеческого фактора ИКАО Doc 9683-AN / 950. URL: http://spbguga.ru/ files/04-5-01-005.pdf (дата звернення: 05.02.2021).

12. Серйозний інцидент з ПС Piper-30 N-918Y в аеропорту Львів. URL: http://nbaai.gov.ua/enquiry/serjoznyjinczydent-z-ps-piper-30-n-918y-v-aeroportu-lviv/ (дата звернення: 11.02.2021).

13. Сигал К. А. Ответственность перевозчика по Варшавской и Монреальской конвенции об унификации некоторых правил международных воздушных перевозок: сравнительно-правовой анализ. Третья научнопрактическая конференция по воздушному праву. Сборник докладов. Санкт-Петербург, 2013. С. 93-96. 
14. Смыслова Н. Н., Верещагин А. Н., Садиков О. Н. Международное воздушное право : учебник / отв. ред. О. Н. Садиков, А. П. Мовчан; Академия наук СССР. Институт государства и права. Москва : Издательство «Наука», 1980. $350 \mathrm{c.}$

15. Столярський О. В. Правове регулювання міжнародних перевезень: навч. посібник. М-во освіти і науки, молоді та спорту України, Львів. нац. ун-т ім. Івана Франка. Київ : Знання, 2012. 318 с.

16. Цивільний кодекс України від 16 січня 2003 р. Голос України. 2003. № 47-48.

17. Юридична відповідальність у сфрері перевезень повітряним транспортом. URL: http://dictionary.law.com. (дата звернення: 11.02.2021).

18. Abraham H. J. Das Recht der Luftfahrt. Komentar und Quellensammlung. Koln : Berlin, 1960. 278 p.

19. Guldimann W. Internationales Lufttransportrecht. Zurich, 1965, 106 p.

20. Marc McDonald. The Montreal Convention and the Preemption of Air Passenger harm Claims. Technological University Dublin. URL: https://arrow.tudublin.ie/cgi/viewcontent.cgi?article=1018\&context=tfschhmtart (дата звернення: 01.02.2021).

21. Rilse O. Lufthahrt. Stuttgart, 1949. 421 p.

22. Zeitschrift fut Luftrecht. 1978. № 3. 166 p.

\section{References:}

1. Baymuratov M. O. (2008) Mizhnarodne publichne pravo [International public law]. Kharkiv: Odissei.

2. Boyko M. A. (2013) Osobennosty pravovoho rehulyrovanyya mezhdunarodnykh vozdushnykh perevozok [Features of the legal regulation of international air transportation]. Kontsept (electronic journal), vol. 3, pp. 2386-2390. Available at: https://e-koncept.ru/2013/53480.htm (accessed 8 February 2021).

3. Bordunov V. D. (2007) Mezhdunarodnoe vozdushnoe pravo [International air law]. Moscow: Nauchnaya knyha.

4. Zbirnyk normatyvnykh dokumentiv (1986) Konventsiya dlya unifikatsiyi deyakykh pravyl, shcho stosuyut'sya mizhnarodnykh povitryanykh perevezen' (Varshavs'ka Konventsiya) pidpysana u Varshavi 12.10.1929 [The Convention for the Unification of Certain Rules Relating to International Carriage by Air (Warsaw Convention) signed in Warsaw on 12 October 1929]. Kyiv: Politvydav Ukrayiny.

5. Mizhnarodne pravo v dokumentakh (1982) Konventsiya pro mizhnarodnu tsyvil'nu aviatsiyu (Chykaz'ka Konventsiya), pidpysana v Chykaho 07.12.1944 [Convention on International Civil Aviation (Chicago Convention), signed in Chicago on December 7, 1944]. Moscow: Yurlit.

6. Ofitsiynyy visnyk Ukrayiny (2009) Konventsiya pro unifikatsiyu deyakykh pravyl mizhnarodnykh povitryanykh perevezen' (Monreal's'ka konventsiya) vid 28.05.1999 [Convention for the Unification of Certain Rules for International Carriage by Air (Montreal Convention) of 28 May 1999].

7. Korotkyy T. R. Zbyttya avialaynera MAU v Irani: mizhnarodni standarty rozsliduvannya aviatsiynykh podiy ta intsydentiv [UIA downing in Iran: international standards for investigating aviation incidents]. Ukrayins'ke pravo (electronic journal). Available at: https://ukrainepravo.com/international_law/public_international_law/ zbyttya-avialaynera-mau-v-irani-mau-v-irani-mizhnarodni-standarty-rozsliduvannya-aviatsiynykh-podiy-/ (accessed 5 February 2021).

8. Malovats'kyy O. V. (2007) Mizhnarodno-pravove spivrobitnytstvo derzhav shchodo udoskonalennya Varshavs'koyi systemy vidpovidal'nosti aviapereviznyka [International legal cooperation of states on improving the Warsaw air carrier liability system]. Naukovyy visnyk Dyplomatychnoyi akademiyi Ukrayiny, vol. 13, pp. 165-171.

9. Nakaz Derzhavnoyi aviatsiynoyi sluzhby Ukrayiny vid 26.11.2018 № 1239 «Pro zatverdzhennya Aviatsiynykh pravyl Ukrayiny "Pravyla povitryanykh perevezen' ta obsluhovuvannya pasazhyriv i bahazhu» [Order of the State Aviation Service of Ukraine dated 26.11.2018 № 1239 "On approval of the Aviation Rules of Ukraine" Rules of air transportation and servicing of passengers and luggage"]. Available at: https://zakon.rada.gov.ua/ laws/show/z0141-19\#Text (accessed 15 February 2021).

10. Ostroumov N. N. (2009) Dohovor perevozky v mezhdunarodnom vozdushnom soobshchenyy [Contract of carriage in international air traffic]. Moscow: Statut.

11. Rukovodstvo po obuchenyyu v oblasty chelovecheskoho faktora YKAO Doc 9683-AN/950 [ICAO Human Factors Training Manual Doc 9683-AN / 950]. Available at: http://spbguga.ru/files/04-5-01-005.pdf (accessed 5 February 2021).

12. Seryoznyy intsydent z PS Piper-30 N-918Y v aeroportu Lviv [Serious incident with Piper-30 N-918Y aircraft at Lviv airport]. Available at: http://nbaai.gov.ua/enquiry/serjoznyj-inczydent-z-ps-piper-30-n-918y-v-aeroportu-lviv/ (accessed 11 February 2021).

13. Syhal K. A. (2013) Otvetstvennost' perevozchyka po Varshavskoy y Monreal'skoy konventsyy ob unyfykatsyy nekotorykh pravyl mezhdunarodnykh vozdushnykh perevozok: sravnytel'no-pravovoy analyz [Carrier's liability under the Warsaw and Montreal conventions for the unification of certain rules for international air carriage: a comparative legal analysis]. Proceedings of the Tret'ya nauchno-praktycheskaya konferentsyya po vozdushnomu pravu (Russia, St.Petersburg, 2013), St.Petersburg, pp. 93-96.

14. Smyslova N. N., Vereshchahyn A. N., Sadykov O. N. (1980) Mezhdunarodnoe vozdushnoe pravo [International air law]. Moscow: Nauka.

15. Stolyars'kyy O. V. (2012) Pravove rehulyuvannya mizhnarodnykh perevezen' [Legal regulation of international transportation]. Kyiv: Znannya.

16. Holos Ukrayiny (2003) Tsyvil'nyy kodeks Ukrayiny vid 16 sichnya 2003 [The Civil Code of Ukraine of January 16, 2003].

17. Yurydychna vidpovidal'nist' u sferi perevezen' povitryanym transportom [Legal liability in the field of air transport]. Available at: http://dictionary.law.com (accessed 11 February 2021).

18. Abraham H. J. (1960) Das Recht der Luftfahrt. Komentar und Quellensammlung. Koln: Berlin.

19. Guldimann W. (1965) Internationales Lufttransportrecht. Zurich.

20. Marc McDonald. The Montreal Convention and the Preemption of Air Passenger harm Claims. Technological University Dublin. Available at: https://arrow.tudublin.ie/cgi/viewcontent.cgi?article=1018\&context=tfschhmtart (accessed 1 February 2021).

21. Rilse O. (1949) Lufthahrt. Stuttgart.

22. Zeitschrift fut Luftrecht, 1978, no. 3, 166 p. 